\title{
Celiac disease as potential obstacle to childbearing
}

\author{
Mónika Kovács $^{1 *}$, Mária Szenes ${ }^{1}$, Tihamér Horváth ${ }^{2}$, György Vajda ${ }^{2}$, Beáta Gasztonyi ${ }^{1}$, \\ György Bártfai ${ }^{3}$ \\ ${ }^{1}$ Department of Internal Medicine, Zala County Hospital, Zalaegerszeg, Hungary \\ ${ }^{2}$ Department of Obstetrics and Gynecology, Zala County Hospital, Zalaegerszeg, Hungary \\ ${ }^{3}$ Faculty of Medicine Obstetrics and Gynecology Department, Albert Szent-Györgyi Clinical Center of University Szeged, Szeged, \\ Hungary \\ Email: * $\underline{\text { monika.kovacs.dr@freemail.hu }}$
}

Received 25 December 2013; revised 18 January 2014; accepted 25 January 2014

Copyright (c) 2014 Mónika Kovács et al. This is an open access article distributed under the Creative Commons Attribution License, which permits unrestricted use, distribution, and reproduction in any medium, provided the original work is properly cited. In accordance of the Creative Commons Attribution License all Copyrights (C) 2014 are reserved for SCIRP and the owner of the intellectual property Mónika Kovács et al. All Copyright (C) 2014 are guarded by law and by SCIRP as a guardian.

\section{ABSTRACT}

AIM: The authors have aimed at confirming or excluding gluten sensitivity in infertile couples. PATIENTS AND METHODS: Between 2004 and 2010, at our outpatient clinics of immunology, both partners of 223 couples, who had striven for having a child unsuccessfully, underwent history taking, physical examination, laboratory and immuno-serologic tests including anti-tissue-transglutaminase antibody (antitTG), as well as deep duodenal biopsy in antibody-carrying patients. RESULTS: Antibodies against tissue transglutaminase were positive in 6/223 female patients of whom the diagnosis of celiac disease was histologically confirmed in $3 / 223$ cases $(1.34 \%)$. Of the male patients $2 / 223(0.9 \%)$ have proven to be carriers of the antibody; histology was pathognomonic in both of them. Curiously, one of the male patients with celiac disease has been the partner of a woman who also had celiac disease diagnosed by the authors. In the followup period, a female patient and the female member of the couple with celiac disease gave birth to healthy newborns after spontaneous conception, as the result of a strictly kept gluten-free diet, as well as occasional treatments of acetylsalicylate for antiphos-pholipid syndrome or levothyroxine for latent hypothyroidism due to autoimmune thyroiditis. CONCLUSION: The results underline that it is worth performing a screening for celiac disease in both partners of couples assessed due to the lack of success in having a child, as infertility can be ceased by an appropriate diet.

\section{KEYWORDS}

\section{Celiac Disease; Gluten-Free Diet;}

${ }^{*}$ Corresponding author.
Anti-Tissue-Transglutaminase Antibody; Infertile Couples

\section{INTRODUCTION}

Celiac disease (CD) is an autoimmune process developing in genetically susceptible individuals exposed to the effects of certain environmental factors. 95\% of patients are HLA-DQ2 positive, in addition they often carry HLA-DQ8 allele and there may be other underlying genetic factors as well. However, genetic susceptibility alone is not enough for manifesting the pathognomonic signs and symptoms of the disease; exposition to the gluten content of wheat, barley or rye is also essential; this recognition is the source of the condition's other name, gluten-sensitive enteropathy. In the sera of patients there are auto-antibodies of which anti-endomysium, anti-gliadin and anti-tissue-transglutaminase (anti-tTG) antibodies are of particular importance [1].

Tissue transglutaminase enzyme that plays a part in cellular apoptosis, enters the extracellular space upon the cell's injury due to the gliadin component of gluten, and results in the development of neoantigens and peptides with strong negative charge [1]. By activating $\mathrm{CD}^{4+} \mathrm{T}$ cells, these antigens induce a Th1 immune response, the effector phase of which implies the destruction of intestinal mucosa in the small bowels by CD8+ T cells, natural killer cells and matrix metalloproteinases of fibroblast origin [1]. In addition to the positive immuno-serological findings, histopathological examination of the affected intestinal mucosa and demonstration of villous atrophy are always required for the diagnosis of $\mathrm{CD}$.

Gluten sensitivity may produce not only gastrointestinal signs and symptoms, as tissue transglutaminase enzyme is present, among others, in the cells of skin, mu- 
scles, nervous system, and liver so that it may be associated with various clinical signs and symptoms [2]. Of extraintestinal manifestations, infertility is of special importance because gluten sensitivity may be the underlying cause of delayed menarche, early menopause, secondary amenorrhea, infertility, habitual abortions, fetal retardation, premature birth and stillbirth in women, and gonadal dysfunction and abnormalities of sperm in men [3-8].

\section{PATIENTS AND METHODS}

Between September 2004 and September 2010, at the outpatient clinics of immunology in the Zala County Hospital, both partners of 223 couples, who had striven for having a child unsuccessfully, underwent history taking, physical examination, laboratory and immuno-serologic tests including detection of anti-nuclear antibody (ANA) by an immunofluorescent (IF) method; anti-double-stranded-DNA antibody (anti-dsDNA) (cut-off: 25 $120 \mathrm{U} / \mathrm{ml}$ ); anti-cardiolipin antibody (aCl) (cut-off: 10 $100 \mathrm{MPL} / \mathrm{ml}$ and 10 - $104 \mathrm{GPL} / \mathrm{ml}$ ); anti-phosphatidylserine antibody (aPS) (>15 U/ml); anti-beta-2 glycoprotein 1 antibody (aß2GP1) (>10 U/ml); anti-prothrombin antibody (aPT) $(>10 \mathrm{U} / \mathrm{ml})$; anti-annexin $\mathrm{V}$ antibody (aANX) $(>5 \mathrm{U} / \mathrm{ml})$; antibodies against extractable nuclear antigens (ENA-profile) $(>1.2 \mathrm{U} / \mathrm{ml})$; anti-thyroid-peroxidase antibody (anti-TPO) (cut-off: 0 - 30 $\mathrm{U} / \mathrm{ml}$ ); anti-tissue-transglutaminase antibody (anti-tTG) (cut-off: 0 - $7 \mathrm{U} / \mathrm{ml}$ ); and anti-sperm antibody (a-sperm) enzyme-linked immunosorbent assay (ELISA). In addition, our anti-tTG positive patients underwent deep duodenal biopsy for histological examination in order to confirm the diagnosis of CD.

\subsection{Case Reports}

\subsubsection{Case 1}

In November 2007 we examined the 35-year-old female patient after her $4^{\text {th }}$ unsuccessful in vitro fertilization (IVF). Her medical history included supplements of iron on several occasions in her childhood because of developing anemia; and she reported on having permanent diarrhea. The laboratory findings seen at her assessment (Hgb: $135 \mathrm{~g} / \mathrm{l}$; Htc: 0.39 1/l; serum Fe: $38.3 \mu \mathrm{mol} / \mathrm{l}$; serum ferritin: $23.2 \mathrm{ng} / \mathrm{ml}$; serum vitamin B12: $350 \mathrm{pg} / \mathrm{ml}$; serum folic acid: $20 \mathrm{ng} / \mathrm{ml}$; serum total protein: $72 \mathrm{~g} / \mathrm{l}$; serum albumin: $44 \mathrm{~g} / \mathrm{l}$ ) showed no abnormal values suggesting any malabsorption. Immuno-serological tests demonstrated anti-tTG positivity $(46.6 \mathrm{U} / \mathrm{ml})$ and carrying of a-sperm antibody. In order to confirm CD, we planned deep duodenal biopsy; however the patient began a gluten-free diet immediately after having known the immuno-serological findings.

In December 2007 the patient reported on a spontane- ously conceived pregnancy, so we cancelled the planed endoscopy. In addition to a strict gluten-free diet, the patient received supplementation of iron and folic acid during her pregnancy. The immuno-serological tests performed after her $22^{\text {nd }}$ week of gestation indicated yet positive anti-tTG $(14.7 \mathrm{U} / \mathrm{ml})$, but its titer showed a decreasing tendency.

In August 2008 she delivered a healthy female newborn (birth weight: $3400 \mathrm{~g}$ ) in the $40^{\text {th }}$ week of her pregnancy.

Follow-up testing of the nursing mother, performed in November 2008, demonstrated an already negative anti-tTG (5.68 U/ml) (Table 1).

\subsubsection{Case 2}

In May 2009 we examined the 31-year-old female patient after two spontaneous abortions (AB) each of which occurred in the $8^{\text {th }}$ week of gestation. Her medical history included keeping a diet since childhood because of obesity (at the time of her examination: body weight: $92 \mathrm{~kg}$; height: $170 \mathrm{~cm}$; BMI: $32 \mathrm{~kg} / \mathrm{m}^{2}$ ). Her laboratory findings (Hgb: $138 \mathrm{~g} / \mathrm{l}$; Htc: 0.41 1/1; serum Fe: $15.3 \mu \mathrm{mol} / \mathrm{l}$; serum ferritin: $18 \mathrm{ng} / \mathrm{ml}$; serum vitamin B12: $578.4 \mathrm{pg} / \mathrm{ml}$; serum folic acid: $7.34 \mathrm{ng} / \mathrm{ml}$; serum total protein: $70 \mathrm{~g} / \mathrm{l}$; serum albumin: $44 \mathrm{~g} / \mathrm{l}$ ) showed no abnormal values. The

Table 1. Anti-tTG antibody positivity among female patients.

\begin{tabular}{|c|c|c|c|c|c|}
\hline & History & $\begin{array}{c}\text { anti-tTG } \\
(\mathrm{U} / \mathrm{ml})\end{array}$ & $\begin{array}{l}\text { Associated } \\
\text { antibodies }\end{array}$ & $\begin{array}{c}\text { Deep } \\
\text { duodenal } \\
\text { biopsy }\end{array}$ & Diagnosis \\
\hline 1 & $\begin{array}{c}4 \\
\text { unsuccessful } \\
\text { IVFs }\end{array}$ & 46.6 & a-sperm & $\begin{array}{l}\text { delayed due to } \\
\text { the patient's } \\
\text { spontaneously } \\
\text { developed } \\
\text { pregnancy }\end{array}$ & $\begin{array}{c}\text { celiac } \\
\text { disease }\end{array}$ \\
\hline 2 & $\begin{array}{c}2 \\
\text { spontaneous } \\
\text { ABs } \\
\text { (week 8) }\end{array}$ & 14.2 & $\begin{array}{c}\text { anti-TPO, } \\
\text { aPS (2x) }\end{array}$ & $\begin{array}{l}\text { total } \\
\text { villous } \\
\text { atrophy }\end{array}$ & $\begin{array}{c}\text { celiac } \\
\text { disease, } \\
\text { APS, } \\
\text { autoimmune } \\
\text { thyroiditis }\end{array}$ \\
\hline 3 & $\begin{array}{c}5 \\
\text { unsuccessful } \\
\text { inseminations }\end{array}$ & 23.0 & $\begin{array}{c}\mathrm{aCl}, \\
\mathrm{aPS}(1 \mathrm{x})\end{array}$ & $\begin{array}{l}\text { subtotal villous } \\
\text { atrophy }\end{array}$ & $\begin{array}{c}\text { celiac } \\
\text { disease, APS, } \\
\text { selective IgA } \\
\text { deficiency }\end{array}$ \\
\hline 4 & $\begin{array}{c}1 \text { delivery, then } \\
2 \text { spontaneous } \\
\text { ABs }\end{array}$ & 53.6 & - & negative & - \\
\hline 5 & $\begin{array}{l}2 \text { spontaneous } \\
\text { ABs, } \\
3 \text { unsuccessful } \\
\text { IVFs }\end{array}$ & 57.9 & - & negative & - \\
\hline 6 & $\begin{array}{c}1 \text { artificial } \mathrm{AB} \text {, } \\
1 \text { spontaneous } \\
\mathrm{AB}\end{array}$ & 33.8 & $\begin{array}{c}\text { aPS, aANX } \\
(1 \mathrm{x})\end{array}$ & negative & APS \\
\hline
\end{tabular}

AB: abortion, aANX: anti-Annexin V antibody, aCl: anti-cardiolipin antibody, aPS: anti-phosphatidylserine antibody, APS: antiphospholipid syndrome, anti-TPO: anti-thyroid peroxidase antibody, anti-tTG: anti-tissuetransglutaminase antibody, IgA: immunoglobulin A, IVF: in vitro fertilization. 
immuno-serological tests demonstrated the positivity of her anti-tTG (14.2 U/ml), anti-TPO (158.2 U/ml), and aPS values (on two occasions with an interval of 6 weeks). Based on the total villous atrophy seen in a tissue sample obtained from her duodenum, the diagnosis of CD was confirmed in the patient. In addition, latent hypothyroidism which developed due to autoimmune thyroiditis (TSH: 8.49 mU/l; FT3: 5.51 pmol/l; FT4: 9.23 pmol/l) and antiphospholipid syndrome (APS) (2 abortions in early pregnancy, aPS positivity) were also revealed. We initiated gluten-free diet and acetylsalicylate (ASA) $(100 \mathrm{mg} /$ day $)$ as well as levothyroxine $(50 \mu \mathrm{g} /$ day $)$ therapy, on which the patient, due to other causes, delayed planning a pregnancy temporarily (Table 1).

\subsubsection{Case 3}

In May 2009 we examined the 30-year-old female patient after 5 unsuccessful inseminations. Her medical history included treatment for bronchial asthma in childhood and permanent constipation. Her laboratory findings (Hgb: $134 \mathrm{~g} / \mathrm{l}$; Htc: 0.41 1/1; serum Fe: $7.4 \mu \mathrm{mol} / \mathrm{l}$; serum ferritin: $28.7 \mathrm{ng} / \mathrm{ml}$; serum vitamin B12: $344 \mathrm{pg} / \mathrm{ml}$; serum folic acid: $20 \mathrm{ng} / \mathrm{ml}$; serum total protein: $69 \mathrm{~g} / \mathrm{l}$; serum albumin: $45 \mathrm{~g} / \mathrm{l}$ ) showed slight iron deficiency and selective IgA deficiency (serum IgA: $0.67 \mathrm{~g} / \mathrm{l}$; serum IgG: 10.89 g/l; serum IgM: $0.84 \mathrm{~g} / \mathrm{l}$ ). The immuno-serological tests demonstrated the positivity of anti-tTG $(23 \mathrm{U} / \mathrm{ml})$ and $\mathrm{aCl}$ (it could be detected only on one occasion, it turned to negative already after 6 weeks). Based on the subtotal villous atrophy confirmed by histological examination, we diagnosed $\mathrm{CD}$ at which we recommended further observation for selective IgA deficiency and APS. The patient kept a strict gluten-free diet and received also ASA (100 mg/day) therapy (Table 1).

\subsubsection{Case 4}

The 34-year-old male patient, examined in May 2009, had no complaints. However, his laboratory findings (Hgb: 143 g/l; Htc: 0.44 1/1; serum Fe: $4.9 \mu \mathrm{mol} / 1$; serum ferritin: $3.4 \mathrm{ng} / \mathrm{ml}$; serum vitamin B12: $389 \mathrm{pg} / \mathrm{ml}$; serum folic acid: $2.86 \mathrm{ng} / \mathrm{ml}$; serum total protein: $63 \mathrm{~g} / \mathrm{l}$; serum albumin: $41 \mathrm{~g} / \mathrm{l}$ ) indicated iron and folic acid deficiency and slight hypoproteinemia. Of his immuno-serological results, anti-tTG (76.1 U/ml) has proven to be positive and the aPS showed positivity on one occasion. Histological examination demonstrated total villous atrophy. The findings related to the sperm of this male patient with CD showed normal values concerning all examined parameters including the number, shape and motion of his sperm cells. The patient started gluten-free diet (Table 2).

Curiously, the partner of the above male patient with CD was a female patient with CD, APS, and selective IgA deficiency, also diagnosed by us (Tables 1 and 2).
Table 2. Anti-tTG antibody positivity among male patients.

\begin{tabular}{|c|c|c|c|c|c|}
\hline & $\begin{array}{l}\text { Partner's } \\
\text { History }\end{array}$ & $\begin{array}{c}\text { anti-tTG } \\
(\mathrm{U} / \mathrm{ml})\end{array}$ & $\begin{array}{l}\text { Associated } \\
\text { antibodies }\end{array}$ & $\begin{array}{c}\text { Deep } \\
\text { duodenal } \\
\text { biopsy }\end{array}$ & $\begin{array}{l}\text { Sperm } \\
\text { findings }\end{array}$ \\
\hline 1 & $\begin{array}{l}5 \text { unsuccessful } \\
\text { inseminations }\end{array}$ & 76.1 & aPS (1x) & $\begin{array}{l}\text { total villous } \\
\text { atrophy }\end{array}$ & $\begin{array}{c}\text { normal } \\
\text { parameters }\end{array}$ \\
\hline 2 & $\begin{array}{c}2 \text { spontaneous } \\
\text { ABs, } \\
1 \text { unsuccessful } \\
\text { IVF }\end{array}$ & 104 & aPS (1x) & $\begin{array}{l}\text { total villous } \\
\text { atrophy }\end{array}$ & $\begin{array}{c}\text { normal } \\
\text { parameters }\end{array}$ \\
\hline
\end{tabular}

AB: abortion, aPS: anti-phosphatidylserine antibody, APS: antiphospholipid syndrome, anti-tTG: anti-tissue-transglutaminase antibody, IVF: in vitro fertilization.

Their genetic testing detected HLA-DQ2 homozygous state in both of them. The couple with gluten sensitivity commonly continued keeping a strict gluten-free diet. In November 2009-as no spontaneous conception occurred up to that time- she underwent IVF which ended with no success.

In March 2010 another IVF was planned, however the menstruation of the female patient delayed and her pregnancy test indicated spontaneously conceived gravidity. The pregnant woman with CD underwent regular medical and gynecologic follow-ups and no overt state of deficiency (iron, vitamin B12, folic acid) could be detected during her pregnancy. In October 2010, in the $26^{\text {th }}$ week of her pregnancy her anti-tTG has already proven to be negative $(0.52 \mathrm{U} / \mathrm{ml})$. In January 2011 she delivered a healthy newborn (birth weight: $2980 \mathrm{~g}$ ) in the $38^{\text {th }}$ week of her gestation.

\section{RESULTS}

There was anti-tTG positivity in 6/223 female patients of whom the diagnosis of celiac disease was histologically confirmed in 3/223 cases (1.34\%) (Table 1 ).

Among male patients 2/223 (0.9\%) anti-tTG positivity has been demonstrated; histology was pathognomonic for CD in both of them (Table 2). The examination of sperm showed normal parameters in both cases.

\section{DISCUSSION}

At first in 1888 Samuel Gee reported on a reversible atrophy of intestinal mucosa of the small bowels leading to malabsorption in patients showing certain genetic susceptibility [9]. The term celiac disease was used first time by the Dutch pediatrician Dicke in the second half of the 1940's; at that time gluten sensitivity was observed exclusively in children [9]. Up to now the previous notions about CD underwent significant changes as forms of the disease in adult patients, not associated with gastrointestinal symptoms and affecting other organ systems have come more and more to the forefront. Anne Ferguson [10] compared the total patient population with CD 
to an iceberg, the mere small tip of which over the waterline represents the diagnosed cases showing a typical clinical picture, while patients with "silent", "latent" and "potential" celiac disease are located under the waterline. CD is termed as "silent" when the individual is free of symptoms but histological examination may reveal villous atrophy in the small bowels that will normalize upon gluten-free diet. In patients with "latent" celiac disease the villi of intestinal mucosa are normal at a gluten-free diet which is kept at the time of the examination, however there were already abnormal histological findings in the history, which have been ceased upon gluten-free diet. In case of a "potential" CD the immuno-serologic tests and family history are positive for CD, however the histopathologic examination yields a negative result $[4,9$, $10]$.

The prevalence of $\mathrm{CD}$ in the general population is about $0.5 \%$ - $1 \%$ with a female predominance (female/ male: $2 / 1,3 / 1$ ), however the prevalence may vary in the different geographical areas [9]. Gluten sensitivity is often associated with type 1 diabetes mellitus, hypothyroidism, Addison's disease, Turner and Down syndrome $[9,11]$. In spite of the more and more extended screening programs, study results unequivocally show that in 50\% $90 \%$ of individuals with CD the disease will not be diagnosed even nowadays (they form the body of the iceberg), and only the tip of the iceberg continues to come into our field of vision [9]. Undiagnosed patients usually have no gastrointestinal symptoms or only very mild complaints; in these cases gluten sensitivity may be indicated by epilepsy developing as a result of calcification in central nervous system; dental anomalies, endocrinologic conditions (e.g. autoimmune thyroiditis), polyarthritis, depression, or pathologic obstetric-gynecologic states [2,12].

Screening the entire population for CD would be cost-ineffective; however in certain situations, such as in patients with idiopathic infertility, other autoimmune pathologic entities or occurrence of CD among members of their family, the performance of screening tests has relevance [13].

When screening subfertile and infertile women for CD, its prevalence was found to be $2.7 \%$ - 3\% [2,14] and $4 \%$ - 8\% [15] respectively; however Kolho et al. [5,7] found no difference between the prevalence in this group of patients and the general population (2.1\% vs. $2.0 \%)$. Several authors $[4,6,8,11,14]$ reported delayed menarche in women with $\mathrm{CD}$ as compared to healthy controls (Ferguson: $15 \pm 2$ vs. $13.5 \pm 1$ years; Sher: $13.6 \pm 1.6$ vs. $12.7 \pm 1.4$ years; Molteni: 13.5 vs. 12.1 years) as well as early menopause (Ferguson: $45 \pm 5.5$ vs. $53 \pm 1.2$ years; Sher: $47.6 \pm 4.4$ vs. $50.1 \pm 3.5$ years; Molteni: 45.5 vs. 49.5 years). The prevalence of secondary amenorrhea was found much more frequent (39\% vs. 9\%) while the number of born children $(1.9 \pm 0.9$ vs. $2.5 \pm 1.2)$ lower than in their healthy contemporaries $[6,8,11]$. The manifestation of pathological gynecologic conditions showed no correlation with the severity of CD or the nutritional status of patients; however cessation of habitual abortions was observed upon normalization of any potential folic acid deficiency $[11,16]$.

Of pathological obstetric conditions, a correlation between habitual abortions and CD was reported at first by Morris et al. in the 1970's [7]. In women with undiagnosed CD the prevalence of habitual abortions has proven to be considerably higher in several various clinical studies $[6-8,14,17]$ as compared to the group of healthy controls (Ogborn: 21\% vs. 4\%; Molteni: 27 vs. 6.9\%; Sher: 15 vs. 5\%), however Kolho et al. [5] demonstrated no significant difference between the two groups with regard to the prevalence $(1.6 \%)$ of recurring abortions. The importance of the results lies in the fact that in women with already diagnosed CD the number of habitual abortions can be reduced by gluten-free diet (Sher: 15 vs. 7\%; Ciacci: 43.3 vs. 7.7\%; Ferguson: 17.8 vs. $9 \%)[3,4,8,11]$. The prevalence of stillbirth in women with CD is about $5.4 \%$ that can be ceased completely by keeping a strict diet [4]. As obstetrical complications of undetected or untreated gluten sensitivity, preeclampsia, placental abruption and an increased number of deliveries by cesarean section have also been documented [11].

Of fetal malformations, the prevalence of neural tube defects probably connected with vitamin B12 and folic acid deficiency was studied in newborns of mothers with CD. As deficiencies of vitamin B12 and folic acid are fairly infrequent even in undiagnosed or not diet-keeping gluten-sensitive patients, no clear association could be demonstrated between CD and impaired closure of neural tube $[11,18]$. However, every author calls the attention to the importance of assessment for any potentially existing vitamin deficiency and the necessary substitution therapy.

Intrauterine growth retardation (IUGR) and low birth weight ( $\leq 2499 \mathrm{~g}$ ) can be considered as independent risk factors for the future development of certain chronic illnesses such as type 1 and type 2 diabetes mellitus and cardiovascular diseases $[9,19]$. An extremely close and multifaceted relationship is presumed to exist between the presence of CD in the parents and the birth weight of their newborns. A Danish study showed that the birth weight of newborns of mothers with untreated CD was significantly lower (-238 g) as compared to those of healthy control mothers. On the other hand, newborns of mothers with CD who kept a gluten-free diet were delivered with birth weight on average higher by $67 \mathrm{~g}$ in comparison to newborns of healthy mothers examined as negative controls $[11,20,21]$. The above is confirmed also by the observation of Ciacci et al. who found that 
IUGR (seen in $29.4 \%$ of untreated mothers) can be ceased by gluten-free diet, and the duration of breast feeding can be prolonged by 2.5 months [3,11,21].

Deficiencies of iron, folic acid, vitamin B12, zinc and selenium in the mother may be putative underlying causes of IUGR [3,12]. The pathogenic role of deficient states is disputed by others based on the rarity of vitamin and trace element deficiencies even in undiagnosed and untreated women with CD; in addition no unfavorable outcome of pregnancy showed any correlation with the nutritional status of the mother with CD and the severity of her disease $[2,11,14]$. Therefore, beyond states of deficiency, the possibility of further pathogenic factors as underlying causes of IUGR has emerged.

Unfavorable changes in maternal immune system may significantly affect fetal development. In patients with $\mathrm{CD}$ the cytotoxic mononuclear cells which proliferate in association with the immune response to the gliadin content of gluten, and the cytokines produced by them, including interleukin-12 and tumor necrosis factor alpha, leave maternal and enter fetal circulation via the placenta and induce IUGR. If the mother complies with her gluten-free diet appropriately, the immunologic process will discontinue, i.e. the quantity of cytotoxic cells and cytokines will significantly decrease and by this way the fetus's intrauterine development will be undisturbed $[12,19]$.

In men CD exerts a known effect on gonadal function, as teratozoospermia and asthenozoospermia may occur in $46 \%$ and $75 \%$ respectively, what has proven to be reversible upon gluten-free diet $[11,14,22,23]$. In addition, the father's disease may also influence the course of pregnancy and the expected outcome of delivery significantly. Namely, the genomes of both parents have a decisive role in relation to normal embryogenesis and satisfactory placental function, and from this aspect paternal genes may conceivably be even more important than maternal ones [19,23]. Ludvigsson et al. [19] found the birth weight of children whose father had CD (and mother was healthy) significantly lower in comparison to those with a healthy father (3273 g vs. 3596 g), while they found no significant difference between mothers with $\mathrm{CD}$ and healthy women in relation to birth weight (3447 g vs. $3596 \mathrm{~g}$ ). The risk of developing IUGR is fivefold higher in case of fathers with CD than in the general population (11\% vs. 2.5\%) [19,24].

As underlying the low birth weight, a pathogenic role was presumed, attributed to the fathers' carrier state of HLA-DQ2 and DQ8 that can be transmitted to their offspring. However, no retardation has been observed in newborns of fathers with other HLA-associated diseases (type 1 diabetes mellitus), what underlines the by far not negligible function of non-HLA genes in the pathogenesis of CD $[18,24]$. Fetal cytokine production is deter- mined by genetic factors so that, among others, tumor necrosis factor-alpha promoter polymorphism is more frequent in patients with $\mathrm{CD}(32 \%)$ as compared to healthy people (8\%), and its transmission to the offspring may contribute to the development of IUGR [19]. At last, with regard to the child to be born, also the genetic pattern of parents should not be left out of consideration as it determines their immunological processes including the working up of antigens ingested with the food, the specificity of immune responses, the production of cytokines and the paths of signal transduction; however the knowledge and understanding of these requires yet further studies [24].

In the population of CD patients studied by Ludvigsson et al. [19] two full-term (of 40 and 41 weeks of gestation) healthy babies, showing no IUGR, were born whose both parents had CD. Therefore it seems that, in addition to the above detailed genetic and immunologic factors, in relation to the outcome of pregnancies there should certainly be differences between "good" and "very good” gluten-free diets as well [19,24].

\section{CONCLUSION}

Summing up, we can state that gluten sensitivity should be taken into consideration in pathological states of pregnancy even in symptom-free patients. Assessment and therapy of anti-tTG positive patients and follow-up of pregnancies in female patients with $\mathrm{CD}$ always require multidisciplinary cooperation; in addition we wish to emphasize that as for the outcome of pregnancy, also male members of the couples should not be left out of consideration.

\section{REFERENCES}

[1] Sütő, G. (2006) Celiac disease. In: Czirják, L., Ed., Clinical Immunology, Medicina Publishing House, Budapest, 325-326.

[2] Collin, P., Vilska, S., Heinonen, P.K., Hallström, O. and Pikkarainen, P. (1996) Infertility and coeliac disease. Gut, 39, 382-384. http://dx.doi.org/10.1136/gut.39.3.382

[3] Ciacci, C., Cirillo, M., Auriemma, G., Di Dato, G., Sabbatini, F. and Mazzacca, G. (1996) Celiac Disease and Pregnancy Outcome. The American Journal of Gastroenterology, 91, 718-722.

[4] Ferguson, R., Holmes, G.K.T. and Cooke, W.T. (1982) Coeliac disease, fertility and pregnancy. Scandinavian Journal of Gastroenterology, 17, 65-68. http://dx.doi.org/10.3109/00365528209181045

[5] Kolho, K.L., Tiitinem, A., Tulppala, M., Unkila-Kallio, L. and Savilahti, E. (1999) Screening for coeliac disease in women with a history of recurrent miscarriage or infertility. British Journal of Obstetrics and Gynaecology, 106, 171-173. http://dx.doi.org/10.1111/j.1471-0528.1999.tb08218.x 
[6] Molteni, N., Bargella, M.T. and Binchi, P.A. (1990) Obstetric and gynecological problems with untreated sprue. Journal of Clinical Gastroenterology, 12, 37-39. http://dx.doi.org/10.1097/00004836-199002000-00010

[7] Ogborn, A.D.R. (1975) Pregnancy in patients with coeliac disease. British Journal of Obstetrics and Gynaecology, 82, 293-296. http://dx.doi.org/10.1111/j.1471-0528.1975.tb00637.x

[8] Sher, K.S. and Mayberry, J.F. (1994) Female fertility, obstetric and gynaecological history in coeliac disease. Digestion, 55, 243-246. http://dx.doi.org/10.1159/000201155

[9] Goddard, C.J.R. and Gillett, H.R. (2006) Complications of coeliac disease: Are all patients at risk? Postgraduate Medical Journal, 82, 705-712. http://dx.doi.org/10.1136/pgmj.2006.048876

[10] Ferguson, A., Arranz, E. and O’Mahony, S. (1993) Clinical and pathological spectrum of celiac disease-Active, silent, latent, potential. Gut, 34, 150-151. http://dx.doi.org/10.1136/gut.34.2.150

[11] Eliakim, R. and Sherer, D.M. (2001) Celiac Disease: Fertility and Pregnancy. Gynecologic and Obstetric Investigation, 51, 3-7. http://dx.doi.org/10.1159/000052881

[12] Martinelli, P., Troncone, R., Paparo, F., Torre, P., Trapanese, E., Fasano, C., Lamberti, A., Budillon, G., Nardone, G. and Greco, L. (2000) Coeliac disease and unfavourable outcome of pregnancy. Gut, 46, 332-335. http://dx.doi.org/10.1136/gut.46.3.332

[13] Pope, R. and Sheiner, E. (2009) Celiac disease during pregnancy: To screen or not to screen? Archives of Gynecology and Obstetrics, 279, 1-3. http://dx.doi.org/10.1007/s00404-008-0803-4

[14] Meloni, G.F., Dessole, S., Vargiu, N., Tomasi, P.A. and Musumeci, S. (1999) The prevalence of coeliac disease in infertility. Human Reproduction, 14, 2759-2761. http://dx.doi.org/10.1093/humrep/14.11.2759

[15] Jackson, J.E., Rosen, M., McLean, T., Moro, J., Croughan, M. and Cedars, M.I. (2008) Prevalence of celiac

\section{LIST OF ABBREVIATIONS}

aANX: anti-Annexin $\mathrm{V}$ antibody

AB: abortion

aCL: anti-cardiolipin antibody

ANA: antinuclear antibody

aPS: anti-phosphatidyl serine antibody

aPT: anti-prothrombin antibody

aß2GP1: anti-beta-2 glycoprotein 1 antibody

anti-dsDNA: anti-double-stranded DNA antibody

anti-TPO: anti-thyroid peroxidase antibody

anti-tTG: anti-tissue-transglutaminase antibody

APS: antiphospholipid syndrome

a-sperm: anti-sperm antibody

ASA: acetylsalicylic acid

BMI: body-mass index disease in a cohort of women with unexplained infertility. Fertility and Sterility, 89, 1002-1004.

http://dx.doi.org/10.1016/j.fertnstert.2007.04.053

[16] Hirson, C. (1970) Coeliac infertility-Folic acid therapy. Lancet, 295, 412. http://dx.doi.org/10.1016/S0140-6736(70)91537-0

[17] Greco, L., Veneziano, A., Di Donato, L., Zampella, C., Pecoraro, M. and Paladini, D. (2004) Undiagnosed celiac disease does not appear to be associated with unfavourable outcome of pregnancy. Gut, 53, 149-151. http://dx.doi.org/10.1136/gut.53.1.149

[18] Dickey, W., Stewart, F. and Nelson, J. (1996) Screening for coeliac disease as a possible maternal risk factor for neural tube defect. Clinical Genetics, 49, 106-108. http://dx.doi.org/10.1111/j.1399-0004.1996.tb04339.x

[19] Ludvigsson, J.F. and Ludvigsson, J. (2001) Coeliac disease in the father affects the newborn. Gut, 49, 169-175. http://dx.doi.org/10.1136/gut.49.2.169

[20] Norgard, S., Fonager, K., Sorensen, H.T. and Olsen, J. (1999) Birth outcomes of women with celiac disease: A nationwide historical cohort study. The American Journal of Gastroenterology, 94, 2435-2440. http://dx.doi.org/10.1111/j.1572-0241.1999.01370.x

[21] Sheiner, E., Peleg, R. and Levy, A. (2006) Pregnancy outcome of patients known celiac disease. European Journal of Obstetrics \& Gynecology and Reproductive Biology, 129, 41-45. http://dx.doi.org/10.1016/j.ejogrb.2005.10.023

[22] Baker, P.G. and Read, A.E. (1975) Reversible infertility in male coeliac disease. British Medical Journal, 2, 316317. http://dx.doi.org/10.1136/bmj.2.5966.316-a

[23] Farthing, M.J.G., Edwards, C.R.W., Rees, L.H. and Dawson, A.M. (1982) Male gonadal function in coeliac disease: 1 . Sexual dysfunction, infertility, and semen quality. Gut, 23, 608-614. http://dx.doi.org/10.1136/gut.23.7.608

[24] Greco, L. (2001) The father figure in coeliac disease. Gut, 46, 163. http://dx.doi.org/10.1136/gut.49.2.163

CD: celiac disease

ELISA: enzyme-linked immunosorbent assay

ENA-Profile: antibodies against extractable nuclear antigens

Fe: iron

FT3: free tri-jodide-thyronine

FT4: free thyroxin

GPL: IgG phospholipid level

Hgb: hemoglobin

Htc: hematocrit

IF: immunofluorescent method

IUGR: intrauterine growth retardation

IVF: in vitro fertilization

MPL: IgM phospholipid level

TSH: thyroid-stimulating hormone 